\title{
The role of Akt on Arsenic trioxide suppression of 3T3-L1 preadipocyte dif- ferentiation
}

\author{
Zhi Xin WANG ${ }^{1}$, Chun Sun JIANG ${ }^{1}$, Lei LIU ${ }^{1}$, Xiao Hui WANG ${ }^{1}$, Hai Jing JIN ${ }^{1}$, Qiao $\mathrm{WU}^{2}$, Quan CHEN ${ }^{1, *}$ \\ ${ }^{I}$ State Key Laboratory of Biomembrane and Membrane Biotechnology, Institute of Zoology, Chinese Academy of Sciences, \\ Beijing 100080, China \\ ${ }^{2}$ College of life Science, Xiamen University, Xiamen 361005, China
}

\begin{abstract}
The present study investigates the molecular details of how arsenic trioxide inhibits preadipocyte differentiation and examines the role of Akt/PKB in regulation of differentiation and apoptosis. Continual exposure of arsenic trioxide, at the clinic achievable dosage that does not induce apoptosis, suppressed 3T3-L1 cell differentiation into fat cells by inhibiting the expression of PPAR $\gamma$ and $\mathrm{C} / \mathrm{EBP} \alpha$ and disrupting the interaction between PPAR $\gamma$ and RXR $\alpha$, which determines the programming of the adipogenic genes. Interestingly, if we treated the cells for 12 or $24 \mathrm{~h}$ and then withdrew arsenic trioxide, the cells were able to differentiate to the comparable levels of untreated cells as assayed by the activity of GAPDH, the biochemical marker of preadipocyte differentiation. Long term treatment blocked the differentiation and the activity of GAPDH could not recover to the comparable levels of untreated cells. Continual exposure of arsenic trioxide caused accumulation in $\mathrm{G} 2 / \mathrm{M}$ phase and the accumulation of $\mathrm{p} 21$. We found that arsenic trioxide induced the expression and the phosphorylation of Akt/PKB and it inhibited the interaction between Akt/PKB and PPAR $\gamma$. Akt/PKB inhibitor appears to block the arsenic trioxide suppression of differentiation. Our results suggested that Akt/PKB may play a role in suppression of apoptosis and negatively regulate preadipocyte differentiation.
\end{abstract}

Keywords: preadipocyte, cell differentiation, apoptosis, Akt/PKB, Arsenic trioxide.

\section{INTRODUCTION}

Arsenic, a natural constituent of soil and water, is a well-known human carcinogen $[1,2]$. Chronic exposure to inorganic forms of it from drinking water and air pollution can cause many types of cancers such as skin cancer, bladder cancer, liver cancer and kidney cancer. In addition to its carcinogenic effects, arsenic has been linked to type II diabetes mellitus [1] and cardiovascular diseases [2], for example atherosclerosis, hypertension [3], and blackfoot disease [4]. The mechanisms of these effects of arsenic on the development of diseases are not known. But previous studies indicated that alteration of cell proliferation contributes to its carcinogenicity [5]. On the other hand, arsenic has been used to treat cancers and it brings complete remission of acute promyeloid leukemia [6]. This could be due to the induction of differen-

\footnotetext{
*Correspondence: Quan CHEN

Tel: +86-10-62537763; Fax: +86-10-62565689;

E-mail: chenq@ioz.ac.cn
}

tiation at lower dose or induction of apoptosis or autophagic cell death at higher dose [7]. Others and we have reported that arsenic at clinically achievable dosage induced apoptosis by activating mitochondrial dependent apoptosis $[8,9]$. It is not surprising that arsenic trioxide could disrupt multiple signaling pathways for mitogenesis, differentiation, apoptosis and cell cycle control $[10,11]$.

Arsenic has significant impact on the differentiation of cultured cells, including keratinocytes [12] and adipocytes [13]. However, the molecular details for arsenic to inhibit differentiation are still not clear. It is known that the induction of terminal differentiation requires a comprehensive reprogramming of gene expression, and this could occur in parallel with withdrawal from the cell cycle. PPAR $\gamma$ and $\mathrm{C} / \mathrm{EBP} \alpha$ are two important transcription factors governing adipocyte differentiation. PPAR $\gamma$ is a ligand-activated transcription factor that belongs to the nuclear hormone receptor family. It needs to form an active heterodimer with RXR $\alpha$ (Rentinoid X Receptor) to bind to PPAR-response elements (PPRE), and stimulate transcription of the target genes. The cooperation of PPAR $\gamma$ and RXR drives the ex- 
pression of a number of adipocytic genes for preadipocyte to differentiate and to maintain adipogenic phenotype [14]. The serine-threonine protein kinase Akt/PKB, also known as Protein kinase B (PKB), is an important survival factor when cells were stimulated by a number of growth factors or cytokines. It is reported that $\mathrm{Akt} / \mathrm{PKB}$ is a pivotal mediator of the pathway of insulin signaling that induce the differentiation of preadipocyte [15]. Also, it is well documented that Akt/PKB play a critical role in regulating apoptosis. In this paper, we described that arsenic trioxide inhibited preadipocyte differentiation by downregulation of transcription factors of PPAR $\gamma$ and $\mathrm{C} / \mathrm{EBP} \alpha$ and the interaction between PPAR $\gamma$ and its ligand $\mathrm{RXR} \alpha$. We found that Akt/PKB was induced but the interaction between Akt/ PKB and PPAR $\gamma$ was blocked by arsenic trioxide.

\section{MATERIALS AND METHODS}

\section{Cell lines, antibodies and reagents}

Mouse fibroblast line 3T3-L1 preadipocytes (ATCC CL173) were cultured in Dulbecco's modified Eagle's medium (DMEM) (Gibco BRL) containing 10\% fetal bovine serum (Hyclone), $100 \mathrm{U} /$ $\mathrm{ml}$ penicillin and $0.1 \mathrm{mg} / \mathrm{ml}$ streptomycin (Gibco). To induce differentiation, 3T3-L1 preadipocytes were grown to confluence for two days. $2 \mathrm{~d}$ after confluence, cells were induced to differentiate (d 0$)$ with addition of the standard differentiation inducing mix. Insulin (100 nM, Sigma), dexamethasone $(0.25 \mu \mathrm{M}$, Sigma) and isobutylmethylxanthine (IBMX) (0.5 mM, Sigma) were added to the medium for the first $48 \mathrm{~h}$. From day 2 to 6 , the medium was supplemented with $100 \mathrm{nM}$ insulin only. The cells were then switched back to $10 \%$ fetal bovine serum from d 6 to 8 . The cultures were replenished every 2 days. $3 \mu \mathrm{M}$ arsenic trioxide was added into the medium $2 \mathrm{~d}$ prior to the induction and during the induction period. 5 $\mu \mathrm{M}$ Akt/PKB inhibitor (1L-6-Hydroxymethyl-chiro-inositol 2-(R)2-O-methyl-3-O-octadecylcarbonate, Calbiochem) was added into the medium $2 \mathrm{~d}$ prior to the induction in the presence or absence of $3 \mu \mathrm{M}$ arsenic trioxide.

\section{Oil Red O staining}

Dishes were washed three times with phosphate-buffered saline, fixed by $10 \%$ formalin in phosphate buffer for $1 \mathrm{~h}$ at room temperature. After fixation, cells were washed once with phosphate-buffered saline and stained with filtered Oil Red O stock solution $(0.5 \mathrm{~g}$ of Oil Red O (Sigma) in $100 \mathrm{ml}$ isopropyl alcohol) for $2 \mathrm{~h}$ at room temperature. Cells were washed twice with water, visualized and photographed.

\section{Cell apoptosis assay}

Cells were harvested and washed with PBS and then binding buffer. After that, cells were stained with $25 \mathrm{ng} / \mathrm{mL}$ Annexin V-FITC at $37^{\circ} \mathrm{C}$ for $10 \mathrm{~min}$, and stained with PI just before detection. Then Annexin-V positive apoptotic cells was determined by a BD FACScan as previously described [8].

\section{Cell cycle assay}

Cell synchronization

Cells were incubated at the density of $2.5 \times 10^{5}$ cells $/ 150 \mathrm{~mm}^{2}$ in
10\% FBS DMEM. 24h later, cells were washed with PBS and then starved in DMEM containing $0.1 \%$ FBS for $24 \mathrm{~h}$ to synchronize. Then cell cycle was initiated by replacement of the starvation medium with the full medium (DMEM with $10 \%$ FBS). At the same time $3 \mu \mathrm{M}$ arsenic trioxide was added into the medium.

\section{Flow cytometric analysis of cell cycle}

Cell cycle distribution was determined by using fluorescence activated cell sorting (FACS). Briefly, cells were harvested and washed twice with PBS. After centrifugation, pellets were re-suspended in $500 \mu \mathrm{PBS}$, added drop by drop into $5 \mathrm{ml}$ cold $\left(-20^{\circ} \mathrm{C}\right)$ ethanol and fixed at $4^{\circ} \mathrm{C}$ overnight. Before staining, the ethanol was removed and cells were washed twice with $1 \%$ BSA (in PBS). Then cells were resuspended in $400 \mu \mathrm{l}$ PBS containing 1\% BSA. $50 \mu \mathrm{l} 500 \mu \mathrm{g} / \mathrm{ml}$ PI and $50 \mu 10 \mathrm{mg} / \mathrm{ml}$ boiled RNase A were added and cells were incubated at $37^{\circ} \mathrm{C}$ for $30 \mathrm{~min}$ before determination. The proportion of cells in each phase of cell cycle was determined by a BD FACScan.

\section{Determination of enzyme activity of GAPDH}

Cells were washed twice with ice-cold PBS and STEM $(250 \mu \mathrm{M}$ Sucrose, 10 mM Tris-Hcl (PH7.4), 1 mM EDTA, 1 mM 2-Mercaptoethanol), and were scraped down to centrifuge. Then cells were resuspended with $200 \mu \mathrm{l}$ STEM, fractioned by supersonic and centrifuged at $4^{\circ} \mathrm{C}, 12,000 \mathrm{rpm}$ for $30 \mathrm{~min}$. The quantity of protein in supernatant was determined and adjusted to the same level. $240 \mu \mathrm{l}$ reaction buffer (100 mM Triethanolamine (PH 7.7), 0.25 mM EDTA, $1 \mathrm{mM}$ 2-Mercaptoethanol, $0.2 \mathrm{mM}$ NADH), $160 \mu \mathrm{l}$ Dihydroxyacetone phosphate and $400 \mu \mathrm{l}$ STEM plus supernatant were added to a $1 \mathrm{ml}$ quartzose cup. Change of absorbance at $340 \mathrm{~nm}$ was recorded by using a Beckman Spectrophotometer. The activity of GAPDH were computed by the initial velocity of the reaction and showed as $\mathrm{nmol} / \mathrm{min} / \mathrm{mg}$ protein.

\section{Western blotting}

Cells were harvested and washed twice with PBS, then were lysed with lysis buffer at $4^{\circ} \mathrm{C}$ for $30 \mathrm{~min}$. cells were centrifuged at 12 , $000 \mathrm{rpm}, 4^{\circ} \mathrm{C}$ for $15 \mathrm{~min}$. After adjusting the protein concentrations, lysates were boiled with loading buffer at $100^{\circ} \mathrm{C}$ for $10 \mathrm{~min}$. Lysates were run in $12 \%$ polyacrylamide-SDS gels, and transferred to nitrocellulose. The nitrocellulose blots were blocked with phosphate-

Fig. $13 \mu \mathrm{M}$ arsenic trioxide could not induce apoptosis but inhibit differentiation of 3T3-L1 cells. (A) 3T3-L1 cells were treated with 3 $\mu \mathrm{M}$ arsenic trioxide or $0.5 \mu \mathrm{M}$ VP16 for $48 \mathrm{~h}$ and apoptotic cells were determined by flow cytometry. (B-F) 3T3-L1 cells were induced to differentiate. During this process, $3 \mu \mathrm{M}$ arsenic trioxide or $0.5 \mu \mathrm{M}$ VP16 was added into the medium. After $10 \mathrm{~d}$, cells were fixed and stained with Oil Red O. (B) The differentiation-inducting program. (C) Undifferentiated cells. (D) Fully differentiated cells. (E) $3 \mu \mathrm{M}$ arsenic trioxide treated cells. (F) $0.5 \mu \mathrm{M}$ VP16 treated cells. (G) The activity of GAPDH. $3 \mu \mathrm{M}$ arsenic trioxide was added into the induction medium for $0,2,4,6,8,10 \mathrm{~d}$ and then cells were harvested and the activity of GAPDH was examined. (H) The activity of GAPDH. $3 \mu \mathrm{M}$ arsenic trioxide was added into the medium for indicated days during the induction and then was withdrawn, the abscissa indicated the treatment time. Cells were then cultured in normal induction medium and harvested at $\mathrm{d} 8$. 
A
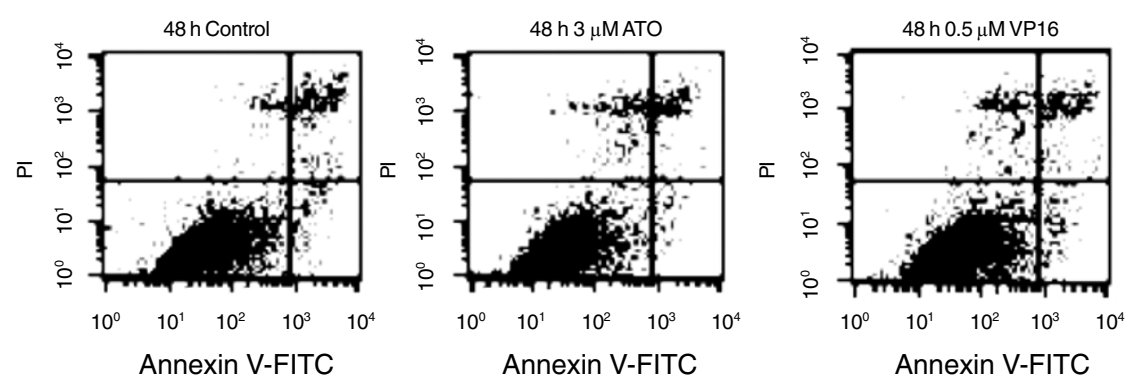

B

The differentiation induction program of 3T3-L1

$\begin{array}{ccccc}\text { Reach } & \text { Add Insulin, } & \text { Add } & \text { Add } & \text { Sample } \\ \text { confluence } & \text { Dexamethasone, } & \text { Insulin } & \text { Insulin } & \text { Harvest } \\ & \text { IBMX } & & & \end{array}$

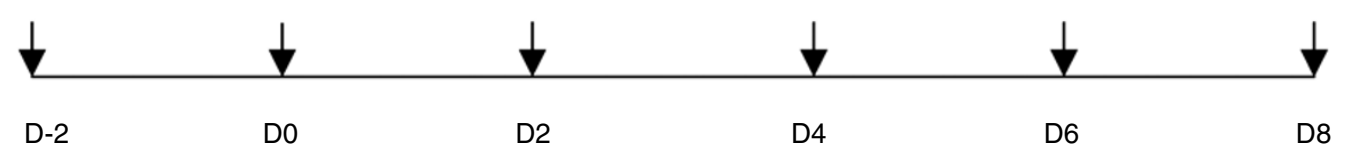

C

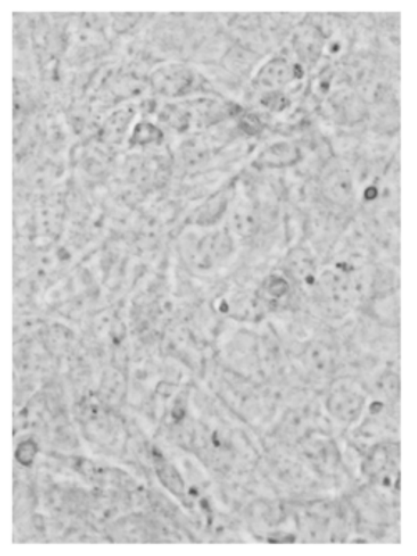

D

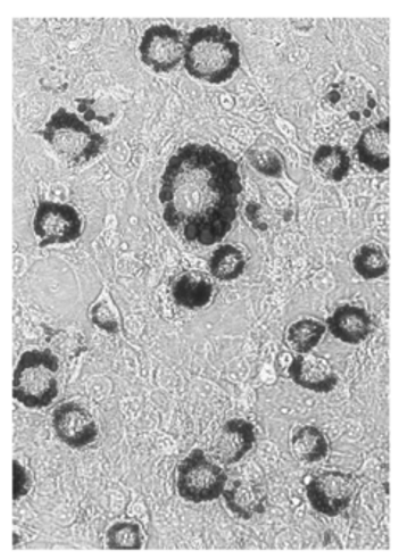

G

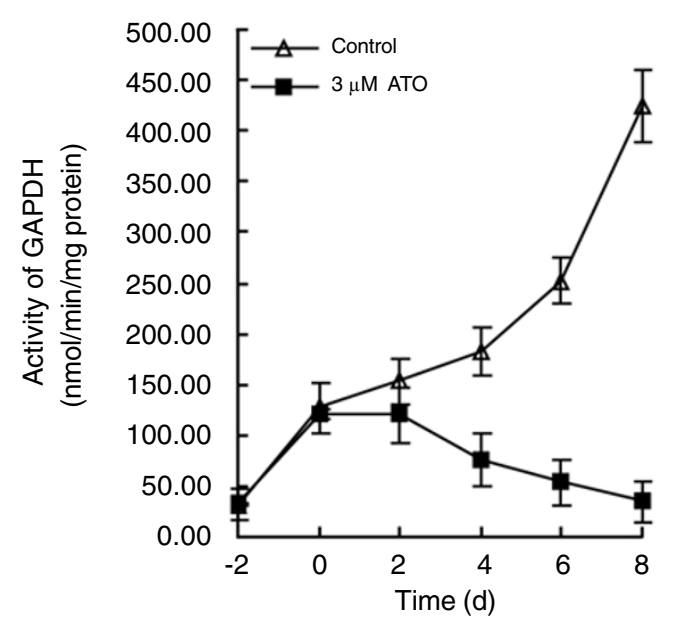

E

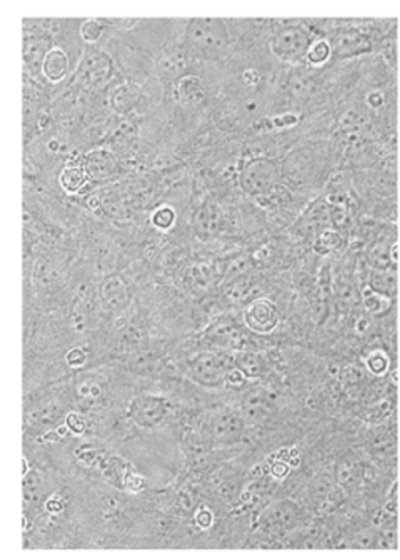

F

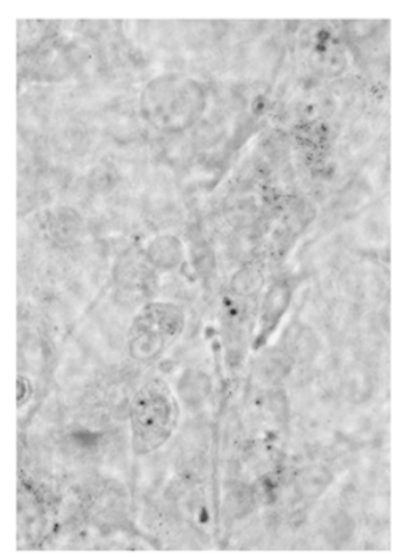

H

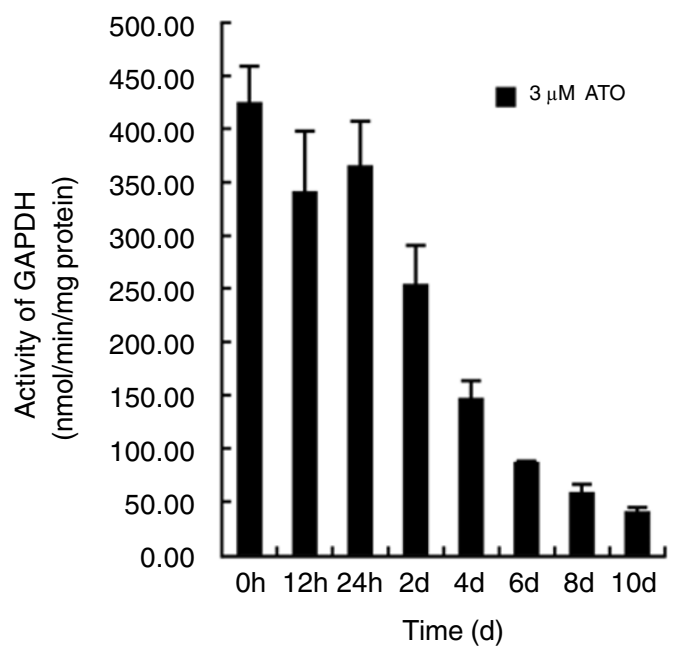


buffered saline containing 5\% non-fat milk and 0.1\% Tween 20 and then treated with antibodies that recognize $\mathrm{p} 21, \mathrm{PPAR} \gamma, \mathrm{C} / \mathrm{EBP} \alpha$ or Akt/PKB, respectively.

\section{Immunoprecipitation}

Cells were harvested and washed twice with PBS, then were lysed with lysis buffer at $4^{\circ} \mathrm{C}$ for $30 \mathrm{~min}$. Cells were centrifuged at $12,000 \mathrm{rpm}$ for $15 \mathrm{~min}$ at $4^{\circ} \mathrm{C}$. Supernatants were carefully collected without disturbing the pellet and transferred to a clean tube. The quantity of protein in them was determined and adjusted to the same level. $2 \mu \mathrm{g}$ PPAR $\gamma$ monoclonal antibody and $500 \mu \mathrm{l}$ lysis buffer were added into the supernatants if it contains $500 \mu \mathrm{g}$ proteins and incubated at $4^{\circ} \mathrm{C}$ overnight. Protein G-argarose was washed thrice with lysis buffer and added $20 \mu \mathrm{l}$ per sample. Then the proteins were incubated at $4^{\circ} \mathrm{C}$ for $2 \mathrm{~h}$. After thrice washing with lysis buffer, proteins were boiled with loading buffer at $100^{\circ} \mathrm{C}$ for $10 \mathrm{~min}$. Then western blotting was performed and antibodies such as RXR $\alpha, \mathrm{Akt} /$ PKB were used.

\section{RESULTS}

Clinic achievable dosage of arsenic trioxide could not induce apoptosis but potently inhibited the differentiation of preadipocyte 3T3-L1

We first examined the effect of arsenic trioxide on cell apoptosis and found that $3 \mu \mathrm{M}$ arsenic trioxide could not induce apoptosis of 3T3-L1 preadipocyte (Fig. 1A) although higher dosage induced cell death (data not shown). We did not detect measurable caspase activity after the treatments with clinic achievable dosage (data not shown). We observed that continual exposure of the cells with 3 $\mu \mathrm{M}$ arsenic trioxide potently inhibited differentiation of 3T3L1 cells as assayed by Oil Red O staining. As shown in Fig. 1D, cells treated with insulin containing differentiation mix were induced to differentiate and obtained morphology with microscopically visible droplets of lipids. In contrast, under the identical conditions, cells grown in 3 $\mu \mathrm{M}$ arsenic trioxide or $0.5 \mu \mathrm{M}$ VP16, a DNA damage agent, did not show lipid accumulation (Fig. 1E and F). We further examined the biochemical marker of preadipocyte differentiation, the appearance of glycerophosphate dehydrogenase (GAPDH). As shown in Fig. 1G, the activity of GAPDH was strongly inhibited by $3 \mu \mathrm{M}$ arsenic trioxide. Interestingly, the cells can continue to differentiate to the comparable levels if we treated the cells for 12 or $24 \mathrm{~h}$ and then withdrew arsenic trioxide (Fig. 1H). If the cells were treated for $48 \mathrm{~h}$ with arsenic trioxide, the differentiation was markedly blocked and the activity of GAPDH could not recover to the comparable levels of untreated cells.

\section{Arsenic trioxide induced slight G2 accumulation of cell cycle and p21 expression}

Because arsenic trioxide and VP16 are both cytotoxic agents, commonly used clinically for treatments of cancers, we next checked their effects on cell cycle of
3T3-L1. Cells were treated with arsenic trioxide after $24 \mathrm{~h}$ serum starvation, and the cell cycle was examined by flow cytometry after PI staining. As shown in Fig. 2A, there was an increase of S phase at $24 \mathrm{~h}$ and accumulation of $\mathrm{G} 2 / \mathrm{M}$ phase at $48 \mathrm{~h}$ after arsenic trioxide treatment, whereas VP16 treated cells were arrested at G2/M 24h after treatment (Fig. 2B and 2C), suggesting that these two agents has distinct effects on cell cycle. At the same time, p21 were increased following arsenic trioxide treatments (Fig. 2D).

\section{Arsenic trioxide inhibited the expression of PPAR $\gamma$ and $\mathrm{C} / \mathrm{EBP} \alpha$}

To understand the molecular mechanisms of arsenic inhibition of preadipocyte differentiation, we next examined the protein levels of PPAR $\gamma$ and $\mathrm{C} / \mathrm{EBP} \alpha$ following the induction of differentiation and the treatment of the cytotoxic agent. As shown in Fig. 3, expression of PPAR $\gamma$ and $\mathrm{C} / \mathrm{EBP} \alpha$ were significantly reduced in arsenic trioxide treated cells in comparison with that of control. There was significant reduction of both PPAR $\gamma 1$ and PPAR $\gamma 2$ expression although there was a fluctuation of PPAR $\gamma 1$ expression following the treatments. These results indicate that arsenic trioxide inhibits lipid accumulation and preadipocyte differentiation by downregulation of the expression of adipocyte transcription factors during differentiation.

\section{Arsenic trioxide inhibited the interaction between $\operatorname{PPAR} \gamma$ and $R X R \boldsymbol{\alpha}$}

Because the interaction between PPAR $\gamma$ and $\operatorname{RXR} \alpha$ is critical for the activity of the transcription complex, we examined the expression of $\mathrm{RXR} \alpha$ and interaction between the two proteins after the treatment of $3 \mu \mathrm{M}$ arsenic trioxide and $0.5 \mu \mathrm{M}$ VP16. Our result showed that the treatment of arsenic trioxide also inhibited the expression of RXR $\alpha$ (Fig. 4A). Importantly, we found that the interaction between PPAR $\gamma$ and RXR $\alpha$ was reduced when treated with arsenic trioxide as assayed by immunoprecipitation (Fig. 4B). Another cytotoxic agent VP16 had minimal effect on the interaction of PPAR $\gamma$ and RXR $\alpha$.

\section{Arsenic trioxide could inhibit the interaction between PPAR $\gamma$ and Akt/PKB}

Having shown that arsenic trioxide strongly suppressed differentiation by disrupting signaling PPAR $\gamma / \mathrm{RxR} \alpha$ pathway, we next examined if Akt/PKB may be involved in mediating the survival signal even when cells were treated with arsenic trioxide. We found that the treatment of arsenic trioxide increased the expression of Akt/PKB compared to that of control which was treated with differentiation mix. Arsenic trioxide significantly enhanced 

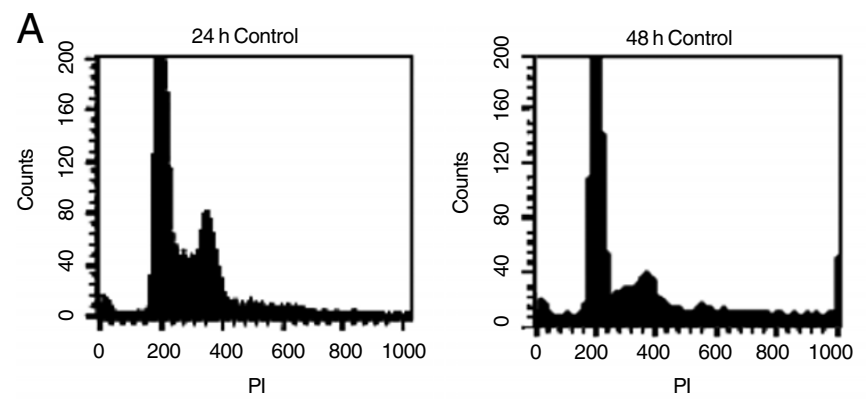

B
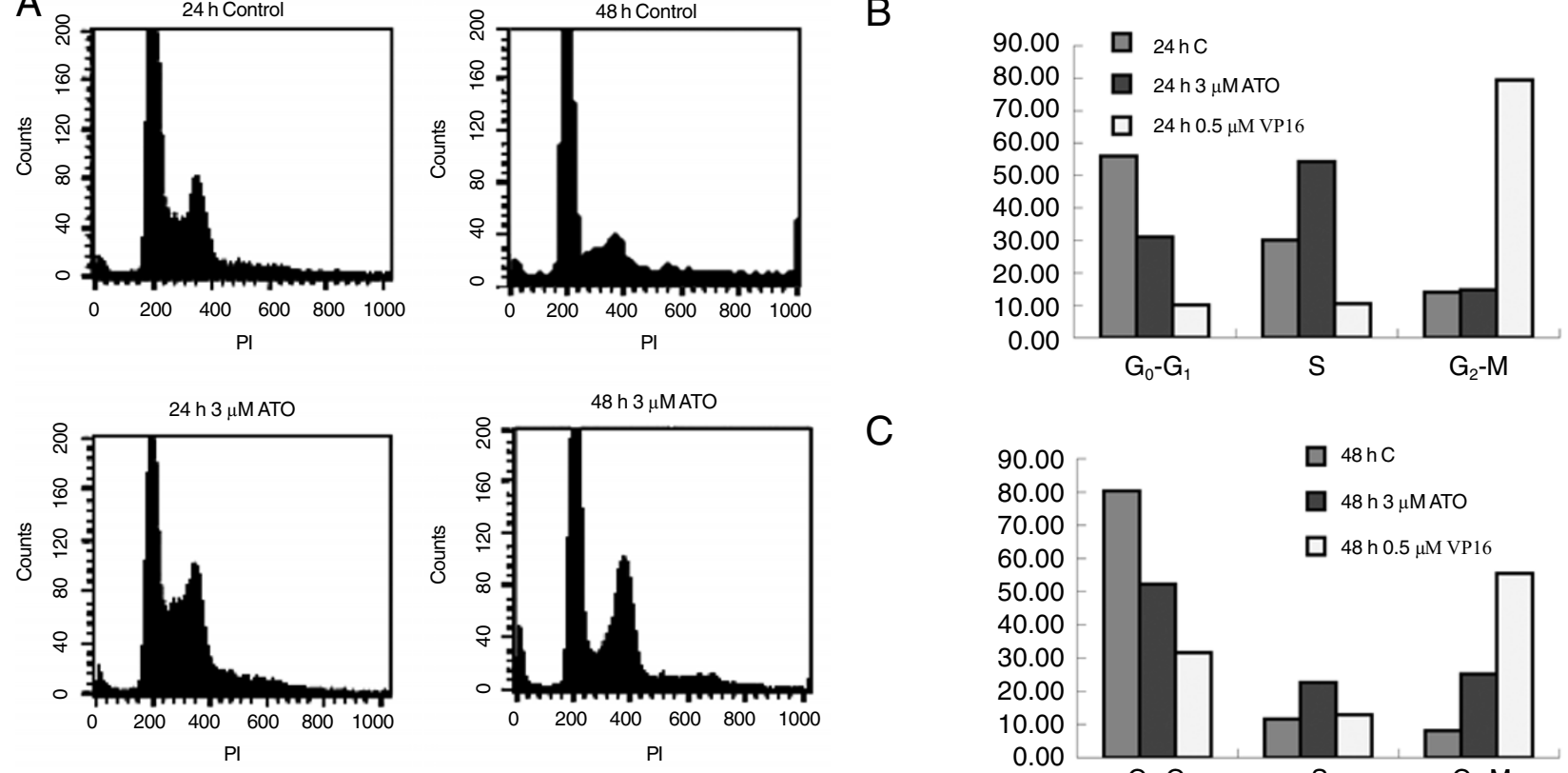

C
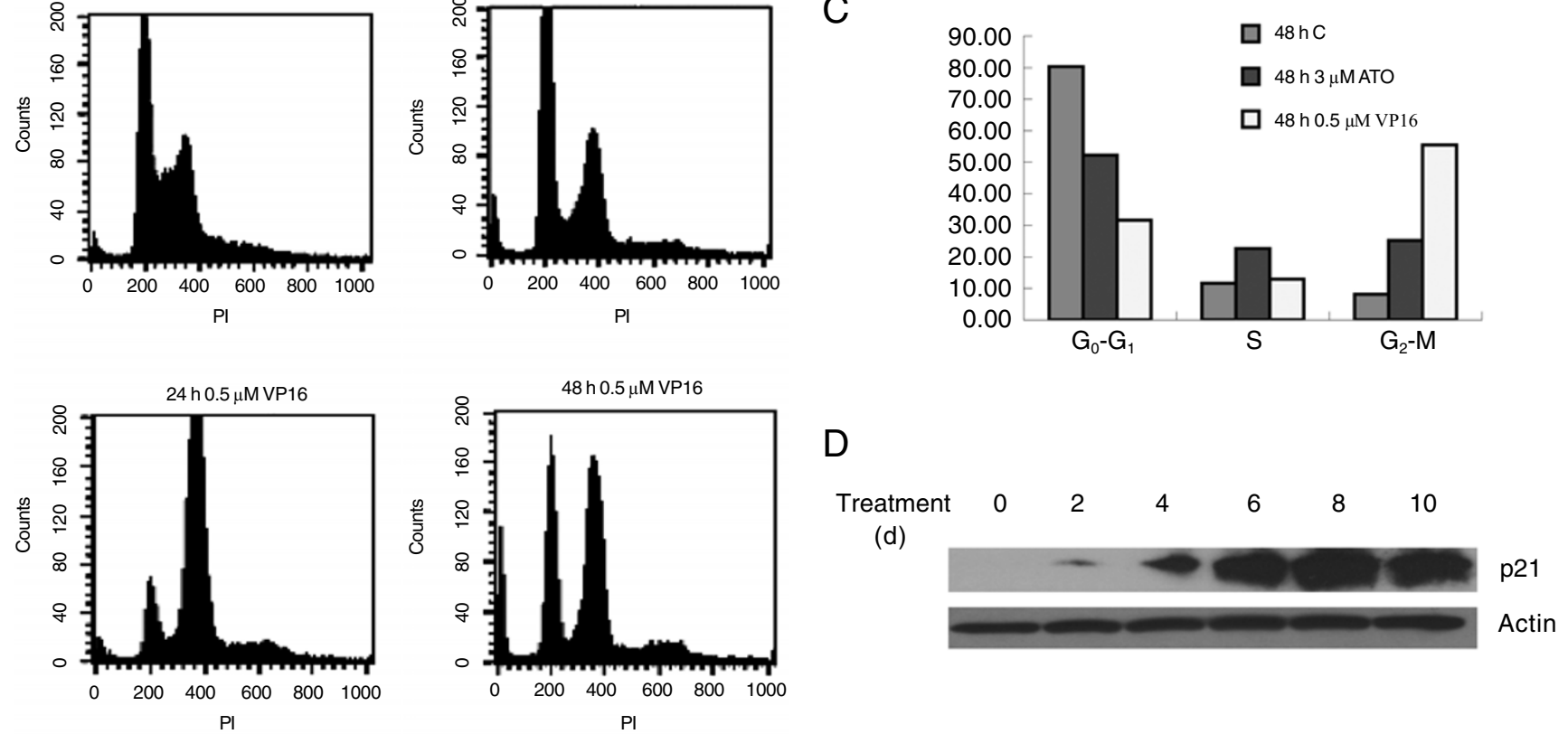

Fig. $23 \mu \mathrm{M}$ arsenic trioxide could induce cell cycle arrest and upregulation of p21. (A) The cell cycles of 3T3-L1 cells were determined by flow cytometry. Cells were synchronized before treatment. After synchronization, $3 \mu \mathrm{M}$ arsenic trioxide or $0.5 \mu \mathrm{M}$ VP16 was added into the medium containing 10\% FBS for 24, 36, $48 \mathrm{~h}$ respectively. (B) arsenic trioxide induced G2 arrest. (C) VP16 induced G2 arrest. (D) p21 was determined by western blotting. 3T3-L1 cells were induced to differentiate. During this process $3 \mu \mathrm{M}$ arsenic trioxide was added into the medium from $\mathrm{d}-2$ for $0,2,4,6,8$ and $10 \mathrm{~d}$ respectively. Then western blotting was performed.

the phosphorylation of Akt/PKB, thereby its activation (Fig. $5 \mathrm{~A}$ ), although the expression of PPAR $\gamma, \mathrm{C} / \mathrm{EBP}$ and RXR was reduced under identical conditions. Interestingly, we found that $\mathrm{Akt} / \mathrm{PKB}$ inhibitor could counteract the repression effect of arsenic trioxide on the differention of 3T3L1. When the 3T3-L1 cells were treated with arsenic trioxide and Akt/PKB inhibitor together, there are more than $90 \%$ of cells accumulate droplets of lipids (see Fig. 5C and D). Furthermore, we showed that Akt/PKB interacted with PPAR $\gamma$ directly and arsenic trioxide could suppress the interaction between Akt/PKB and PPAR $\gamma$ (Fig. 5B). Our results suggest that Akt/PKB could negatively regulate preadipocyte differentiation and may function to suppress apoptosis in the cells when treated with arsenic trioxide.

\section{DISCUSSION}

The current study examined the molecular details of the inhibitory effects of arsenic trioxide on cell differentiation and apoptosis. We found that arsenic trioxide could inhibit the expression of the PPAR $\gamma$ and RXR $\alpha$ and disrupt the interaction between them. We showed that Akt/PKB expression and its phosphorylation are induced upon arsenic trioxide treatment. Terminal differentiation is usually associated with the long term survival. Apart from the induction of the differentiation programme, insulin also activates survival signals. Of note, Akt/PKB, which was found to be a critical molecule for cell survival, is significantly induced by insulin. We found that Akt/PKB expression was induced and it was activated as revealed by phosphorylation upon the treatment of arsenic trioxide, even when the 


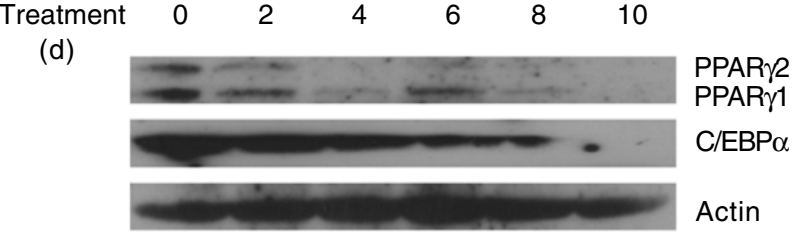

Fig. 3 Arsenic trioxide can decrease the expression of PPAR $\gamma$ and $\mathrm{C} /$ $\mathrm{EBP} \alpha$. PPAR $\gamma$ and $\mathrm{C} / \mathrm{EBP} \alpha$ were determined by western blotting. 3T3-L1 cells were induced to differentiate. During this process 3 $\mu \mathrm{M}$ arsenic trioxide was added into the medium from d-2 for $0,2,4$, 6,8 and 10 d respectively.

\section{A}

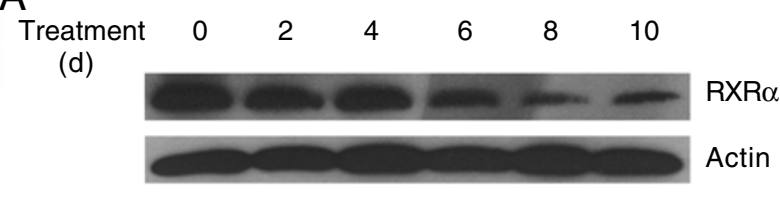

B

\begin{tabular}{|c|c|c|c|c|}
\hline \multicolumn{4}{|c|}{ IP: anti-PPAR $\gamma$} & \\
\hline Und-Control & Fd-Control & ATO & VP16 & \\
\hline
\end{tabular}

Fig. 4 Arsenic trioxide can decrease the expression of RXR $\alpha$ and inhibit the interaction between PPAR $\gamma$ and RXR $\alpha$. 3T3-L1 cells were induced to differentiate. (A) RXR $\alpha$ level was determined by western blotting. During this process $3 \mu \mathrm{M}$ arsenic trioxide were added into the medium from d-2 for $0,2,4,6,8$ and $10 \mathrm{~d}$ respectively. (B) The interaction between PPAR $\gamma$ and RXR $\alpha$ was determined by immunoprecipitation. $3 \mu \mathrm{M}$ arsenic trioxide or $0.5 \mu \mathrm{M}$ VP16 was added into the medium till the end of the induction. (Und-Control: undifferentiated control, Fd-Control: fully differentiated control)

cell differentiation is significantly suppressed. It is interesting to note that $\mathrm{Akt} / \mathrm{PKB}$ can directly interact with PPAR $\gamma$ and arsenic trioxide can inhibit the interaction between them. The reduced interaction is associated with the inhibition of cell differentiation. Of note, we found that Akt/ PKB inhibitor could counteract, at least in part, the repression effect of arsenic trioxide on the differention of 3T3L1 while the inhibitor itself has minimal effects on cell differentiation and cell death. This indicates that the repression effect of arsenic trioxide on the differentiation was depended on the activation of Akt/PKB. This is in agreement with previous report that Akt/PKB- $\alpha$ plays an important role in the regulation of preadipocyte growth and proliferation, and it is down-regulated upon differentiation [16]. Our results are also in agreement with wealth information that $\mathrm{Akt} / \mathrm{PKB}$ functions to suppress apoptosis.
A

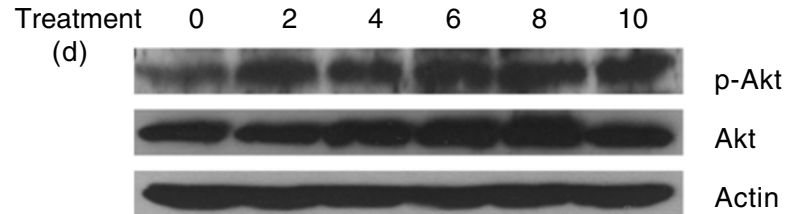

B

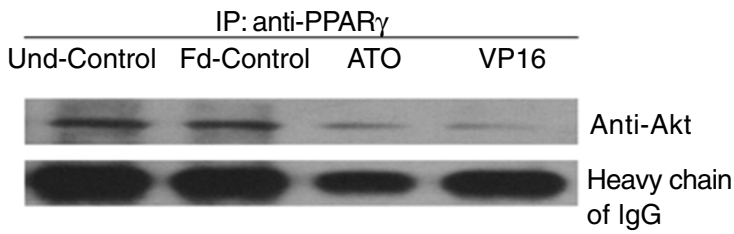

C
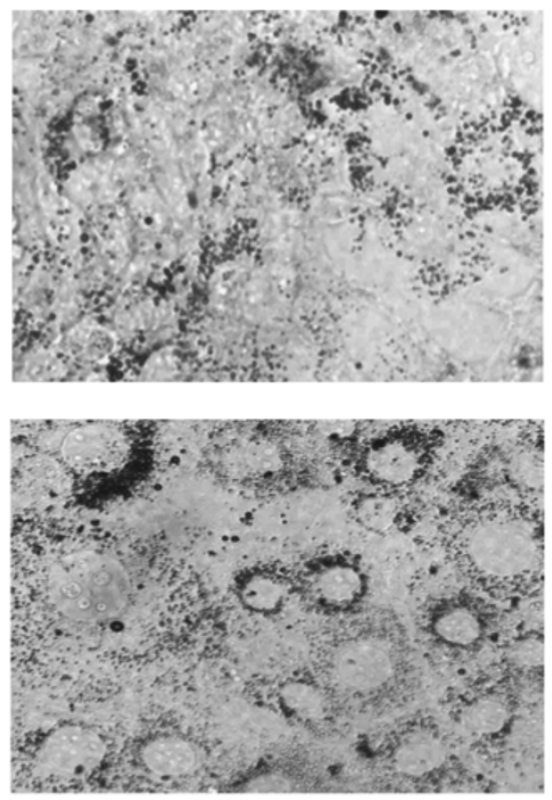

Fig. 5 Arsenic trioxide can inhibit the interaction between PPAR $\gamma$ and Akt. 3T3-L1 cells were induced to differentiate. (A) Akt and pAkt were determined by western blotting. During this process, 3 $\mu \mathrm{M}$ arsenic trioxide was added into the medium from d-2 for $0,2,4$, 6, 8 and $10 \mathrm{~d}$ respectively. (B) The interaction between PPAR $\gamma$ and Akt was determined by immunoprecipitation. $3 \mu \mathrm{M}$ arsenic trioxide or $0.5 \mu \mathrm{M}$ VP16 was added into the medium till the end of the induction. (Und-Control: undifferentiated control, Fd-Control: fully differentiated control) (C, D) Akt inhibitor partially blocks arsenic trioxide inhibition of differentiation. $5 \mu \mathrm{M}$ Akt/PKB inhibitor was added into the medium $2 \mathrm{~d}$ prior to the induction in the absence or presence (see Fig. 1D, 1E respectively for comparison) of $3 \mu \mathrm{M}$ arsenic trioxide. After $10 \mathrm{~d}$, cells were fixed and stained with Oil Red $\mathrm{O}$ (C) $5 \mu \mathrm{M}$ Akt inhibitor treated cells. (D) $5 \mu \mathrm{M}$ Akt inhibitor and $3 \mu \mathrm{M}$ arsenic trioxide treated cells.

It is found that $\mathrm{Akt} / \mathrm{PKB}$ could phosphorylate Bad, a Bcl-2 family protein to suppress apoptosis [17]. Alternatively, Akt/PKB could inhibit Bax conformation change, critical 
events for apoptosis [18]. It should be noted that arsenic trioxide activate a number of signaling pathways, such as MAPK, ERK and JNK or suppress certain signaling pathways $[19,20]$. The molecular details of the network of different signaling molecules to regulate cell differentiation need to be further investigation.

In addition to show that it inhibits the interaction between Akt/PKB and PPAR $\gamma$, we found that arsenic trioxide disrupts the interaction between PPAR $\gamma$ and RXR, critical transcriptional factors functions together to regulate adipogenic genes expression. These results extended previous findings which suggested that sodium arsenite could inhibit the differentiation of another preadipocyte cell line, $\mathrm{C} 3 \mathrm{H} 10 \mathrm{~T} 1 / 2$ by inhibiting the expression of PPAR $\gamma$ and $\mathrm{C} /$ EBP $\alpha$ [21]. It appears that the inhibition of the activity of GAPDH by arsenic trioxide is reversible and preadipocyte differentiation reached the comparable levels between control cells and cells exposed to the short exposure (12, 24 h). There may be a critical decision-making time for the cells to decide their fates between 24 and $48 \mathrm{~h}$. We observed that there was an accumulation of the cells at G2 phase and the increased expression of p21, at 48 h. p21 was also implicated in regulating cell survival. Altiok and his colleague found that PPAR $\gamma$ initiates withdrawal from the cell cycle during adipogenesis [22]. In smooth muscle cells, PPAR $\gamma$ activation results in accumulation of cells in G0/G1 [23]. Our results showed that arsenic trioxide decreased the expression of PPAR $\gamma$, suggesting that it is not likely to be responsible for $\mathrm{G} 2$ accumulation. Our results also is in contrast to the finding that sodium arsenite inhibited the expression of $\mathrm{p} 21$ [21]. Other report suggests that arsenite induced $\mathrm{p} 27$, which is also related to cell cycle entry [24]. This warrants further study of the determination of cell fates under arsenic stress conditions.

In summary, current study corroborates the earlier report that arsenic inhibits differentiation of preadipocytes into adipocytes. We showed that arsenic disrupts adipogenesis via perturbation of the interaction of PPAR $\gamma$ and $\mathrm{RXR} \alpha$ pathway. Importantly, our data suggest that Akt/ PKB could be a major survival signal and negatively regulate cell differentiation. Our results may be useful for understanding of effects of arsenic trioxide in cell death and differentiation.

\section{ACKNOWLEDGEMENTS}

This work is supported by grants from National Nature Science Foundation of China (No.30000083). Quan CHEN's laboratory was supported by grants "Knowledge Innovation Key Project" (kscx2-sw-2010) of Chinese Academy of Sciences, and the National Basic Research Program of China (973 program project, No. 2002CB513100) and National Fund for Outstanding Young
Scholars from NSFC (30325013) awarded to Quan CHEN.

Received, Mar 2, 2005

Revised, Mar 17, 2005

Accepted, Apr 1, 2005

\section{REFERENCES}

1 Tseng CH, Tai TY, Chong CK et al. Long-term arsenic exposure and incidence of non-insulin-dependent diabetes mellitus: a cohort study in arseniasis-hyperendemic villages in Taiwan. Environ Health Perspect 2000; 108:847-51.

2 Engel RR, Hopenhayn-Rich C, Receveur O et al. Vascular effects of chronic arsenic exposure: a review. Epidemiol Rev 1994; 16: 184-209.

3 Rahman M, Tondel M, Ahmad SA et al. Hypertension and arsenic exposure in Bangladesh. Hypertension 1999; 33:74-8.

4 Tseng CH, Chong CK, Chen CJ et al. Dose-response relationship between peripheral vascular disease and ingested inorganic arsenic among residents in blackfoot disease endemic villages in Taiwan. Atherosclerosis 1996; 120:125-33.

5 Germolec DR, Spalding J, Yu HS et al. Arsenic enhancement of skin neoplasia by chronic stimulation of growth factors. Am J Pathol 1998; 153:1775-85.

6 Soignet SL, Maslak P, Wang ZG et al. Complete remission after treatment of acute promyelocytic leukemia with arsenic trioxide. N Engl J Med 1998; 339:1341-8.

7 Zhang TD, Chen GQ, Wang ZG et al. Arsenic trioxide, a therapeutic agent for APL. Oncogene 2001; 20:7146-53.

8 Zheng Y, Shi Y, Tian C et al. Essential role of the voltage-dependent anion channel (VDAC) in mitochondrial permeability transition pore opening and cytochrome $\mathrm{c}$ release induced by arsenic trioxide. Oncogene 2004; 23:1239-47

9 Zheng Y, Yamaguchi H, Tian C et al. Arsenic trioxide $\left(\mathrm{As}_{2} \mathrm{O}_{3}\right)$ induces apoptosis through activation of $\mathrm{Bax}$ in hematopoietic cells. Oncogene 2005; Epub ahead of print.

10 Hamadeh HK, Vargas M, Lee E et al. Arsenic disrupts cellular levels of p53 and mdm2: a potential mechanism of carcinogenesis. Biochem Biophys Res Commun 1999; 263:446-9.

11 Trouba KJ, Glanzer JG, Vorce RL. Wild-type and Ras-transformed fibroblasts display differential mitogenic responses to transient sodium arsenite exposure. Toxicol Sci 1999; 50:7281.

12 Kachinskas DJ, Phillips MA, Qin Q et al. Arsenate perturbation of human keratinocyte differentiation. Cell Growth Differ 1994; 5:1235-41.

13 Trouba KJ, Wauson EM, Vorce RL. Sodium arsenite inhibits terminal differentiation of murine $\mathrm{C} 3 \mathrm{H} 10 \mathrm{~T} 1 / 2$ preadipocytes. Toxicol Appl Pharmacol 2000; 168:25-35.

$14 \mathrm{Wu}$ Z, Rosen ED, Brun R et al. Cross-regulation of C/EBP alpha and PPAR gamma controls the transcriptional pathway of adipogenesis and insulin sensitivity. Mol Cell 1999; 3:151-8.

15 Magun R, Burgering BM, Coffer PJ et al. Expression of a constitutively activated form of protein kinase B (c-Akt) in 3T3-L1 preadipose cells causes spontaneous differentiation. Endocrinology 1996; 137:3590-3.

16 Hill MM, Clark SF, Tucker DF et al. A role for protein kinase Bbeta/Akt2 in insulin-stimulated GLUT4 translocation in adipocytes. Mol Cell Biol. 1999; 19:7771-81.

17 Yamaguchi H, Wang HG The protein kinase PKB/Akt regulates 
cell survival and apoptosis by inhibiting Bax conformational change Oncogene. 2001; 20:7779-86.

18 Neshat MS, Raitano AB, Wang HG et al.The survival function of the Bcr-Abl oncogene is mediated by Bad-dependent and independent pathways: roles for phosphatidylinositol 3-kinase and Raf. Mol Cell Biol. 2000; 20:1179-86.

19 Shim MJ, Kim HJ, Yang SJ et al. Arsenic trioxide induces apoptosis in chronic myelogenous leukemia K562 cells: possible involvement of p38 MAP kinase. J Biochem Mol Biol 2002; 35:377-83.

20 Chen F, Lu Y, Zhang Z et al. Opposite effect of NF-kappa B and c-Jun N-terminal kinase on p53-independent GADD45 induction by arsenite. J Biol Chem 2001; 276:11414-9.
21 Wauson EM, Langan AS, Vorce RL. Sodium arsenite inhibits and reverses expression of adipogenic and fat cell-specific genes during in vitro adipogenesis. Toxicol Sci 2002; 65:211-9.

22 Altiok S, Xu M, Spiegelman BM. PPARgamma induces cell cycle withdrawal: inhibition of E2F/DP DNA-binding activity via downregulation of PP2A. Genes Dev 1997; 11:1987-98.

23 Wakino S, Kintscher U, Kim S et al. Peroxisome proliferatoractivated receptor gamma ligands inhibit retinoblastoma phosphorylation and G1--> S transition in vascular smooth muscle cells. J Biol Chem 2000; 275:22435-41.

24 Trouba KJ, Wauson EM, Vorce RL. Sodium arsenite-induced dysregulation of proteins involved in proliferative signaling. Toxicol Appl Pharmacol 2000; 164:161-70. 